\title{
SOME RECENT BACTERIOLOGICAL AND BIOCHEMICAL STUDIES ON DIARRHEA IN NEWLY BORN CALVES WITH SPECIAL REFERENCE TO DNA FRAGMENTATION IN BLOOD
}

\author{
SAHAR A. ALY ${ }^{1}$; NAGLAA S. SOLIMAN ${ }^{2}$ and ELGEDAWY A.A. ${ }^{3}$ \\ ${ }^{1}$ Biochemistry Dept., Animal Health Research Institute, Dokki \\ ${ }^{2}$ Biology Dept., Faculty of Science, Qassim University, Saudi Arabia \\ ${ }^{3}$ Bacteriology Dept., Animal Health Research Institute, Dokki
}

Received: 17 July 2016; $\quad$ Accepted: 30 July 2016

\begin{abstract}
Rectal swabs and blood samples were collected from (100) diarrheic calves and (20) apparently healthy contact calves using sterile cotton swabs, at different farms in Sharkia Governorate. For hematological and biochemical investigations, a total of 20 blood samples with and without EDTA from healthy animals showed negative bacterial isolation (group 1) and 50blood samples were selected from collected blood samples (100) from animals showed positive bacterial isolation (group 2). Bacteriological examination of fecal samples revealed that E coli was the most prominent cause of calf diarrhea at an incidence of $54.1 \%$, followed by Salmonella species at an incidence of $17.5 \%$ then Campylobacter at an incidence of $10.8 \%$. Proteus valgaris was isolated at an incidence of $10 \%$ then Pseudomonas at an incidence of $6.7 \%$. Serological identification of 65 E. coli isolates, revealed that the E. coli were typed as O157 (38.5\%), O119 (23.1\%), O25 (7.7), O111 (7.7\%), O186 (15.4\%), and untypable E. coli (7.7\%). Bacteriological examination revealed the isolation of Salmonella from diarrheic calves as well as apparently healthy contact calves. S. typhimurium was the most predominant serovars $(52.4 \%)$ which indicates that $\mathrm{S}$. typhimurium is the most predominant serovars causing enteritis in calves. S. enteritidis $(33.3 \%)$ and 3 strains $(14.3 \%)$ were untypable. Results of antibiogram revealed that, ciprofloxacin, cephalexin and ofloxacin) were the most effective antibiotics for treatment of diarrheic calves. Most isolated bacteria showed different degrees of resistance to Ampicillin, Cefotaxime, Gentamycine. PCR results revealed that 16 $(88.9 \%)$ out of 18 examined E coli strains encoding blaTEM gene while only two $(11.1 \%)$ strains were negative. The hematological changes revealed that there was a significant decrease in total red blood cells count, platelets and hemoglobin concentration $(\mathrm{p}<0.05)$ accompanied by higher values of Total leukocyte count (TLC), neutrophilia with lymphopenia recorded in diarrheic calves in comparison with control. Biochemical analysis of positive cases revealed significant increase $(\mathrm{P}<0.05)$ in serum globulin content and decrease in total protein, albumin content, resulting in altered $\mathrm{A} / \mathrm{G}$ ratio, also there was significant increase in urea, creatinine and potassium accompanied by significant decrease in glucose and sodium. In comparison with control amino acid analysis demonstrated significant $(\mathrm{P}<0.05)$ decrease in diseased calves. Inter nucleosomal cleavage of host cell DNA, indicated evidence of apoptosis, there was a direct relationship between DNA fragmentation and malondialdehyde level (MDA) while inverse relation with antioxidants.
\end{abstract}

Key words: diarrhea, calves, E.coli, Salmonilla, amino acid, DNA fragmentation and blood changes

\section{INTRODUCTION}

Calf diarrhea (also known as calf scouring) is a commonly reported disease and a major cause of economic loss to cattle producers.

Calf diarrhea is attributed to both infectious and noninfectious factors multiple enteric pathogens (e.g., viruses, bacteria, and protozoa) are involved in the

Corresponding author: Dr. ELGEDAWY A.A

E-mail address: dr.attia31@yahoo.com

Present address: Bacteriology Dept., Animal Health Research Institute, Dokki development of this disease. Co-infection is frequently observed in diarrheic calves although a single primary pathogen can be the cause in some cases. The prevalence of each of pathogen and disease incidence can vary by geographical location of the farms, farm management practices, and herd size. Bartels et al. (2010) and Izzo et al. (2011).

Although the cattle industry has made great improvements with herd management, animal facilities and care, feeding and nutrition, and timely use of bio-pharmaceutics, calf diarrhea is still problematic due to the multi-factorial nature of the disease. Prevention and control of calf diarrhea 
should be based on a good understanding of the disease complexities such as multiple pathogens Kaper et al. (2004).

Numerous infectious agents have been implicated in calf diarrhea. Bovine practitioners and cattle producers are aware of many enteric pathogens because these primary agents have been known to be involved in calf diarrhea for several decades and still greatly influence current cow-calf operations، The most common cause of neonatal diarrhea is enterotoxigenic E-coli (ETEC) stains that produce the K99 (F5) (5adhesion antigen (commonly referred to as E. coli K99 (+and heat-stable enterotoxin. It should be noted that other patho groups of E. coli, which are usually identified by histopathology, can be missed if the diagnosis focuses on E. coli K99 +alone Nataro and Kaper (1998).

Salmonella enterica colonizes the gastrointestinal tract of clinical salmonellosis. Acute diarrheal disease is most common with $\mathrm{S}$. typhimurium and systemic disease is associated with S. dublin. Calves less than 3 weeks of age are commonly infected by Salmonella. The lesions frequently observed in affected calves involve the pseudomembrane on the mucosa of the small intestine as well as enlargement of the mesenteric lymph nodes. Infected cattle can serve as a source of zoonosis through food-borne routes or direct contact Sojka et al. (1977) and Hughes et al. (1971).

A wide range of hosts. S. entericaserovar Typhimurium (S. typhimurium) and serovar Dublin (S. dublin) are the most common etiologic agents that cause salmonellosis in cattle $\mathrm{S}$. typhimurium is the most common serotype that affects calves.

Tsukano et al. (2015) pointed out that during inflammation and stress in animals amino acids (AA) are used for the synthesis of acute-phase proteins, glucose precursors, plasma proteins, antibodies, free radical scavengers, metabolic cofactors, and hormones. Amino acids are often transported from the muscle to the liver for these purpose, degradation of these amino acids from muscle can also be induced by infection, resulting in further nitrogen loss and muscle wasting (Powanda and Beisel, 2003). Also, as reduced intake is considered a clinical sign of diarrhea (Duff and Galyean 2007), less protein intake via feedstuffs exacerbates the effects of increased nitrogen usage by the body in order to mount an immune response.

Oxidative stress related to diarrhea has been implicated as a major initiator of tissue damages and can affect enzymatic activity, signal transcription and gene expression, especially apoptotic gene AbdElrahman (2011). Enterobacteriaceae increases the production of reactive oxygen species (ROS), high levels of ROS disrupt the inner and outer mitochondrial membranes, inducing the release of the cytochrome-c protein and activating the apoptosis and consequently increase DNA fragmentation Kresse et al. (2007).

During infection, the host produces proteins that are able to chelate metal ions and thus, can restrict the availability of essential metals from invading pathogens. Moreover, the toxicity of metals such as copper can be used as a host defense mechanism to promote bacterial killing. Nutrient limitation by the host and nutrient acquisition by pathogenic bacteria are therefore, crucial processes in the pathogenesis of bacterial infectious diseases, as a result of this competition, bacteria have developed sophisticated acquisition systems to scavenge essential metals from the environment. Moreover, efflux systems are used to eliminate the excess metal ions which might become toxic for the bacterial cell Wakeman and Skaar, (2012).

The present study aimed to:

- Isolation and identification of causative agents of calf diarrhea

- Antibiogram to isolated organisms to choose the most effective treatment.

- Detect of the blaTEM gene among isolated E coli strains using PCR as a recent, rapid and accurate method to avoid some drug resistance in order to facilitate medication of affected calves.

- Find out the effect of calf diarrhea on different hematobiochemical aspect especially DNA fragmentation and amino acids in diarrheic calves

\section{MATERIALS AND METHODS}

\section{Collection of samples:}

Rectal swabs were collected from (100) diarrheic calves and (20) apparently healthy contact calves using sterile cotton swabs, at different farms of Sharkia Governorate in Egypt. Samples were transferred directly to the laboratory in a separate clean sterile plastic bag, in an ice box and kept in retail package under complete aseptic condition without delay and subjected to required investigations.

For hematological and biochemical investigations ,A total of 20 blood samples were collected with and without EDTA from apparently healthy animals showed negative bacterial isolation (group 1), also, 50 blood samples were selected from (100) collected blood samples with and without EDTA from positive bacterial isolation animals (group 2).

\section{Bacteriological examination:}

\section{1- Isolation and identification of E. coli:}

All samples were inoculated into tubes of freshly prepared nutrient broth and incubated aerobically at 
$37^{\circ} \mathrm{C}$ overnight, followed by subculturing onto MacConkey agar and eosin methylene blue agar plates for 24-48 hours.

Lactose positive colonies were confirmed as E.coli according to Gershwin (1990); Koneman et al. (1992) and Quinn et al. (1994).

Suspected colonies were subjected to further identifications according to (Edwards and Ewing, 1972).

\section{2- Salmonella isolation and identification:}

Fecal samples were inoculated into selenit-F and tetrathionate broth for enrichment for $16 \mathrm{~h}$ at $37^{\circ} \mathrm{C}$. A loopfull of the broth were streaked onto XLD agar, MacConkey agar and SS. agar plates and incubated at $37^{\circ} \mathrm{C}$ for $37-48 \mathrm{~h}$ and the suspected colonies were identified morphologically, then biochemically using the APl-20E kit system (Biomeraux, France) and serologically according to the Kauffman - white scheme by slide agglutination test using polyvalent and monavalent $\mathrm{O}$ antigen (Difco Laboratories, Detroit, Michigan, USA) and $\mathrm{H}$ antisera (Difco Laboratories, Detroit, Michigan, USA). Cultivation and identification were applied.

According to Morifnigo et al. (1986) and ChirinoTrejo (1999).

\section{3- Isolation of Campylobacter:}

According to Klein et al. (2012), fecal samples were enriched in Bolton brothfor $48 \mathrm{~h}$ at $42^{\circ} \mathrm{C}$ under micro aerophilic conditions (10\% CO2, 5\% O2 and $85 \%$ N2). A loopful of this enrichment was streaked onto modified charcoal cefoperazon deoxycholate agar and a second loopful onto Campy Food Agar. Both plates were incubated at $42^{\circ} \mathrm{C}$ for $48 \mathrm{~h}$ under microaerophilic conditions. Additionally, fecal material without prior enrichment was directly streaked on modified charcoal cefoperazon deoxycholate agar and Campy Food Agar, and incubated at $42^{\circ} \mathrm{C}$ for $48 \mathrm{~h}$. Morphological typical colonies were differentiated by aerobic incubation.

4- Each fecal sample was also cultured onto $5 \%$ sheep blood agar, incubated at $37^{\circ} \mathrm{C}$ for $24 \mathrm{~h}$ and inspected for the presence of other bacterial pathogens, e.g. Bacillus spp., Corynebacterium spp., Pseudomonas Aeruginosa.

\section{5- Sensitivity test}

Antimicrobial agents and media:

The sensitivity test of the isolated organisms to different antimicrobial agents was done using Oxoid discs including $10 \mathrm{mcg}$ ampicillin (AM), $30 \mathrm{mcg}$ cefotaxime (CTX), $5 \mathrm{mcg}$ ciprof-loxacin (CIP), 10 mcg gentamycin $(\mathrm{GN}), 30 \mathrm{mcg}$ cephalexine (CFX) and $5 \mathrm{mcg}$ ofloxacin (OFF). The media used was Muller Hinton medium. According to WHO (1977).

\section{Test procedure:}

The method used was the standard disc diffusion method according to National Committee for Clinical laboratory Standards (NCCLS), 2002 and WHO (1977) (standards, percentage of sensitivity was calculated as described by Bauer et al. (1966) and Fazlani et al. (2001).

Detection of bla TEM gene in isolated E.coli strains by PCR:

\section{Extraction of DNA}

It was performed using the QIAamp DNA Mini kit (Qiagen, Germany, GmbH). Briefly, $200 \mu \mathrm{l}$ of bacterial isolates suspension (18 E coli isolated were incubated with $10 \mu \mathrm{l}$ of proteinase $\mathrm{K}$ and $200 \mu \mathrm{l}$ of lysis buffer at $56^{\circ} \mathrm{C}$ for $10 \mathrm{~min}$. After incubation, 200 $\mu \mathrm{l}$ of $100 \%$ ethanol was added to the lysate. The samples were then washed and centrifuged following the manufacturer's recommendations. Nucleic acid was eluted with $100 \mu$ l of elution buffer provided in the kit.

\section{Quantificaion of DNA:}

Concentration and purity of DNA samples from (Qiagen, Germany, GmbH) kits were determined by measuring absorbance at 260 and $280 \mathrm{~nm}$ using an Bio-Rad biophotometer (Biorad-Japan) with each DNA sample diluted 1:100.

\section{Oligonucleotide primers used in CPCR}

They have specific sequence and amplify a specific product Metabion (Germany) and Biobasic (Canada).

Table 1: Primers sequences, target gene and ampliconsize.

\begin{tabular}{cccc}
\hline Primer & Sequence & Amplified product & Reference \\
\hline \multirow{2}{*}{ F $_{T E M}$} & F:ATCAGCAATAAACCAGC & & Colom et al., 2003 \\
& R:CCCCGAAGAACGTTTTC & & \\
\hline
\end{tabular}

PCR amplification:

Preparation of PCR Master Mixaccording to Emerald Amp GT PCR mastermix (Takara) Code No. RR310Akit. 
Table 2: Reaction component of PCR.

\begin{tabular}{cc}
\hline Volume/reaction & Component \\
\hline $\mathbf{1 2 . 5} \boldsymbol{\mu l}$ & Emerald Amp GT PCR mastermix (2x premix) \\
\hline $\mathbf{4 . 5} \boldsymbol{\mu l}$ & PCR grade water \\
\hline $\mathbf{1} \boldsymbol{\mu} \boldsymbol{l}$ & Forward primer (20 pmol) \\
\hline $\mathbf{1} \boldsymbol{\mu l}$ & Reverse primer (20 pmol) \\
\hline $\mathbf{6} \boldsymbol{\mu l}$ & Template DNA \\
\hline $\mathbf{2 5} \boldsymbol{\mu l}$ & Total \\
\hline
\end{tabular}

Table 3: Cycling conditions of the primers during cPCR Temperature and time conditions of the two primers during PCR according to specific authors and Emerald Amp GT PCR mastermix (Takara) kit.

\begin{tabular}{ccccccc}
\hline Gene & $\begin{array}{c}\text { Primary } \\
\text { denaturation }\end{array}$ & $\begin{array}{c}\text { Secondary } \\
\text { denaturation }\end{array}$ & Annealing & Extension & No. of cycles & Final extension \\
\hline \multirow{2}{*}{$b l a_{T E M}$} & $94^{\circ} \mathrm{C}$ & $94^{\circ} \mathrm{C}$ & $54^{\circ} \mathrm{C}$ & $72^{\circ} \mathrm{C}$ & 35 & $72^{\circ} \mathrm{C}$ \\
& $5 \mathrm{~min}$. & $30 \mathrm{sec}$ & $45 \mathrm{sec}$ & $45 \mathrm{sec}$ & $10 \mathrm{~min}$. \\
\hline
\end{tabular}

The reaction was performed in an Applied biosystem 2720 thermal cycler.

\section{Analysis of the PCR Products:}

The products of PCR were separated by electrophoresis on $1.5 \%$ agarose gel (Applichem, Germany, GmbH) in 1x TBE buffer at room temperature using gradients of $5 \mathrm{~V} / \mathrm{cm}$. For gel analysis, $15 \mu \mathrm{l}$ of the product was loaded in each gel slot. A gelpilot 100 bp plus DNA Ladder (Qiagen, Germany, GmbH) was used to determine the fragment sizes. The gel was photographed by a gel documentation system (Alpha Innotech, Biometra) and the data was analyzed through computer software (Automatic Image Capture Software, Protein Simple formerly cell biosciences, USA).

\section{Hematological and Biochemical examination}

Whole blood was collected in EDTA vials from both groups for hematological examination according to the method described by Jain (2000) and for determination of DNA fragmentation according to the method of (Perandones et al., 1993).

The collected plasma and serum were kept at $-20^{\circ} \mathrm{C}$ till used. Estimation of glutathione -S-transferase (Habig and Jakoby, 1974), lipid peroxidase (Oh Kawa et al., 1975) and Superoxide dismutase (Woolliams et al., 1983) were carried out in plasma. The obtained sera were also used for assay of essential aminoacids [threonine (Thr), methionine (Met), Isoleucine (Ilu), Leucine (Leu), Phenylalanine (Phe), histadine (His) lysine (Lys), arginine (Arg) and valine ( Val)] and non-essential amino acids[serine (ser), glutamic acid (glu), glycine (gln) alanine (aln) cysteine (Cys) and Tyrosine (Tyr] (Csomos and Sarkadi 2002) copper and zinc (Mert and Henkin, 1971) vitamin A (Suzuki, and Katoh 1990) vitamin E (Hawk, et al., 1954), total proteins, albumin, glucose, Urea, Creatinine sodium and potassium spectrophotometrically by using standardized testkits supplied from Bio-Merieux (Bains/France).

\section{Statistical analysis}

The mean values obtained from hemograms and biochemical assays of positive samples were compared with results of negative samples using the T- test (Milton and Toskos, 1985). Differences were considered to be statistically significant with values of $\mathrm{P}<0.05$.

\section{RESULTS}

\section{Bacteriological findings:}

Table 4: Prevalence of bacterial isolates in the examined fecal samples.

\begin{tabular}{|c|c|c|c|c|c|c|c|}
\hline \multirow[t]{2}{*}{ Bacterial species } & \multirow[t]{2}{*}{ NO.* } & \multicolumn{2}{|c|}{ Diseased cases } & \multicolumn{2}{|c|}{$\begin{array}{c}\text { Apparently } \\
\text { healthy cases }\end{array}$} & \multicolumn{2}{|c|}{ Total } \\
\hline & & No. & $\%$ & No. & $\%$ & No. & $\%$ \\
\hline E. coli & 120 & 50 & 41.7 & 15 & 12.5 & 65 & 54.1 \\
\hline Salmonella & 120 & 20 & 16.7 & 1 & 0.83 & 21 & 17.5 \\
\hline Campylobacter & 120 & 10 & 8.3 & 3 & 2.5 & 13 & 10.8 \\
\hline Proteus vulgaris & 120 & 7 & 6.7 & 5 & 3.3 & 12 & 10 \\
\hline Pseudomonas aeriginosa & 120 & 8 & 6.7 & - & - & 8 & 6.7 \\
\hline Total & 120 & 95 & 80.1 & 24 & 20 & 119 & 99.2 \\
\hline
\end{tabular}

NO.*: number of examined samples

$\% \quad$ : calculated according to the number of examined samples 
Table 5: Frequencies and distribution of E. coli serotypes recovered from examined fecal samples.

\begin{tabular}{ccc}
\hline E. coli serotypes & No. of isolates & $\%$ \\
\hline 0157 & 25 & 38.5 \\
\hline 0119 & 15 & 23.1 \\
\hline 025 & 5 & 7.7 \\
\hline 0111 & 5 & 7.7 \\
\hline O186 & 10 & 15.4 \\
\hline Untypable & 5 & 7.7 \\
\hline Total & 65 & 100 \\
\hline
\end{tabular}

The percentage was calculated according to the number of E. coli isolates.

Table 6: Incidence and distribution of Salmonella serotypes recovered from examined fecal samples.

\begin{tabular}{ccc}
\hline Salmonella serotypes & No. of isolates & $\%$ \\
\hline S. typhimurium & 11 & 52.4 \\
\hline S. entertidis & 7 & 33.3 \\
\hline Untypable & 3 & 14.3 \\
\hline Total & 21 & 100 \\
\hline
\end{tabular}

The percentage was calculated according to the number of Salmonella isolates.

Table 7: Sensetivity percentage of bacteria isolated from feces of both diarrheic and apparently healthy calves.

\begin{tabular}{|c|c|c|c|c|c|c|c|c|c|c|c|c|c|}
\hline \multirow{3}{*}{$\begin{array}{l}\text { Bacterial } \\
\text { species }\end{array}$} & \multirow{3}{*}{$\begin{array}{c}\text { No. of } \\
\text { isolates }\end{array}$} & \multicolumn{12}{|c|}{ Antibiotics tested } \\
\hline & & \multicolumn{2}{|c|}{$\mathbf{A M}$} & \multicolumn{2}{|c|}{ CFX } & \multicolumn{2}{|c|}{ CIP } & \multicolumn{2}{|c|}{ CTX } & \multicolumn{2}{|c|}{ GN } & \multicolumn{2}{|c|}{ OFF } \\
\hline & & No. & $\%$ & No. & $\%$ & No. & $\%$ & No. & $\%$ & No. & $\%$ & No. & $\%$ \\
\hline E. coli & 65 & $\mathbf{0}$ & $\mathbf{0}$ & 65 & 100 & 65 & 100 & 25 & 38 & 1 & 0.01 & 65 & 100 \\
\hline Salmonella & 21 & 5 & 23 & 20 & 95 & 19 & 90.4 & 13 & 61 & 3 & 14.2 & 20 & 95.2 \\
\hline Campylobacter & 13 & 10 & 76 & 13 & 100 & 13 & 100 & 10 & 77 & 9 & 69.2 & 12 & 92.3 \\
\hline $\begin{array}{l}\text { Proteus } \\
\text { vulgaris }\end{array}$ & 12 & 6 & 50 & 12 & 100 & 11 & 91 & 10 & 83.3 & 5 & 41.7 & 12 & 100 \\
\hline $\begin{array}{l}\text { Pseudomonas } \\
\text { aeriginosa }\end{array}$ & 8 & $\mathbf{0}$ & $\mathbf{0}$ & 8 & 100 & 7 & 87 & 3 & 37 & 1 & 12 & 7 & 87 \\
\hline
\end{tabular}

No $=$ number of sensitive isolate

The percentage was calculated according to the total number of tested strains

Table 8 \& fig. 1: PCR results showed the detection of blaTEM gene among E. coli serotypes.

\begin{tabular}{cccc}
\hline E. coli serotypes & $\begin{array}{c}\text { No. of examined } \\
\text { isolates }\end{array}$ & $\begin{array}{c}\text { blaTEM positive } \\
\text { strains }\end{array}$ & blaTEM negative strains \\
\hline 0157 & 3 & 3 & 0 \\
\hline 0119 & 3 & 3 & 0 \\
\hline 025 & 3 & 2 & 1 \\
\hline 0111 & 3 & 2 & 1 \\
\hline O186 & 3 & 3 & 0 \\
\hline Untypable & 3 & 3 & 0 \\
\hline Total & 18 & 16 & 2 \\
\hline
\end{tabular}




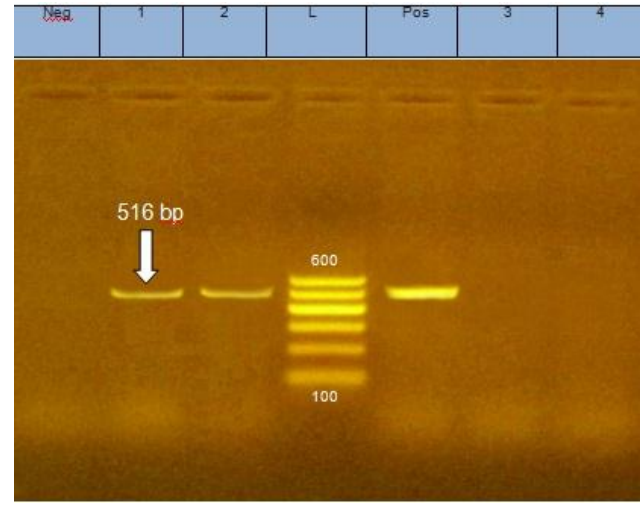

Fig. 1:

L: ladder $100 \mathrm{bp}$

Pos: positive control

Neg: negative control

Lane 1 and 2: positive result at fragment size 516

Lane 3 and 4: negative result with no amplification

Table 9: Some hematological parameters in healthy and diseased calves (mean \pm SE).

\begin{tabular}{|c|c|c|c|c|c|c|c|c|c|}
\hline$\frac{\text { Parameter }}{\text { Groups }}$ & $\begin{array}{c}\text { T.RBCs } \times \\
\left(10^{6} / \mu \mathrm{l}\right)\end{array}$ & $\begin{array}{c}\mathrm{Hb} \\
\mathrm{gm} / \mathrm{dl}\end{array}$ & $\begin{array}{c}\text { Platelets } \\
\left(10^{3} / \mu \mathrm{l}\right)\end{array}$ & $\begin{array}{l}\text { TLC } \times \\
\left(10^{3} / \mu \mathrm{l}\right)\end{array}$ & $\begin{array}{c}\text { lympho } \\
(\%)\end{array}$ & $\begin{array}{c}\text { Neutro } \\
(\%)\end{array}$ & $\begin{array}{c}\text { Eosino } \\
(\%)\end{array}$ & $\begin{array}{c}\text { Mono } \\
(\%)\end{array}$ & $\begin{array}{c}\text { Baso } \\
(\%)\end{array}$ \\
\hline $\begin{array}{l}\text { Control } \\
\text { Group }\end{array}$ & $\begin{array}{c}7.72 \pm \\
0.44\end{array}$ & $\begin{array}{c}11.62 \pm \\
0.36\end{array}$ & $\begin{array}{c}210 \pm \\
1.73\end{array}$ & $\begin{array}{c}5.89 \pm \\
0.77\end{array}$ & $\begin{array}{c}46.22 \pm \\
0.06\end{array}$ & $\begin{array}{c}44.68 \\
\pm 0.077\end{array}$ & $\begin{array}{l}3.16 \pm \\
0.005\end{array}$ & $\begin{array}{l}3.66 \pm \\
0.003\end{array}$ & $\begin{array}{c}2.44 \\
\pm 0.12\end{array}$ \\
\hline $\begin{array}{l}\text { Infected } \\
\text { Group }\end{array}$ & $\begin{array}{c}6.28 * \pm \\
0.17\end{array}$ & $\begin{array}{c}9.18^{*} \pm \\
0.27\end{array}$ & $\begin{array}{l}162 * \\
\pm 0.65\end{array}$ & $\begin{array}{c}8.23 * \pm \\
0.58\end{array}$ & $\begin{array}{c}39.77 * \pm \\
0.09\end{array}$ & $\begin{array}{l}54.88 * \\
\pm 0.074\end{array}$ & $\begin{array}{l}3.08 * \\
\pm 0.04\end{array}$ & $\begin{array}{c}3.88 \\
\pm 0.018\end{array}$ & $\begin{array}{l}2.66 \pm \\
0.07\end{array}$ \\
\hline
\end{tabular}

The mean difference is significant at the $\mathrm{P}<0.05$

Table 10: Some biochemical parameters in healthy and diseased calves (Mean \pm SE).

\begin{tabular}{|c|c|c|c|c|c|c|c|c|c|}
\hline Parameter & Total & Albumin & Globulin & & & Creatinine & Glucose & & K \\
\hline Groups & (g/dl) & (a/dI) & (a/d) & Ratio & (mg/dl) & (mo/dl) & (mg/dl) & $(\mathbf{m E q} . / \mathbf{L})$ & $\mathrm{q} \cdot / \mathrm{L})$ \\
\hline $\begin{array}{l}\text { Control } \\
\text { Group }\end{array}$ & $\begin{array}{c}7.20 \\
\pm 0.24\end{array}$ & $\begin{array}{l}3.22 \\
\pm 0.36\end{array}$ & $\begin{array}{c}3.98 \\
\pm 0.19\end{array}$ & $\begin{array}{l}0.081 \\
\pm 0.03\end{array}$ & $\begin{array}{l}16.20 \\
\pm 0.57\end{array}$ & $\begin{array}{c}0.89 \\
\pm 0.005 \\
\end{array}$ & $\begin{array}{r}79.66 \\
\pm 0.83 \\
\end{array}$ & $\begin{array}{r}145.4 \\
\pm 0.19\end{array}$ & $\begin{array}{c}4.80 \\
\pm 1.73 \\
\end{array}$ \\
\hline $\begin{array}{c}\text { Infected } \\
\text { Group }\end{array}$ & $\begin{array}{c}6.78 * \\
\pm 0.17\end{array}$ & $\begin{array}{l}2.65 * \\
\pm 0.27\end{array}$ & $\begin{array}{l}4.13 * \\
\pm 0.65\end{array}$ & $\begin{array}{l}0.64 * \\
\pm 0.02\end{array}$ & $\begin{array}{c}29.35^{*} \\
\pm 0.94\end{array}$ & $\begin{array}{l}1.43 * \\
\pm 0.04\end{array}$ & $\begin{array}{l}44.88 * \\
\pm 0.48\end{array}$ & $\begin{array}{c}112.80 * \\
\pm 0.75\end{array}$ & $\begin{array}{l}6.60 * \\
\pm 0.65\end{array}$ \\
\hline
\end{tabular}

The mean difference is significant at the $\mathrm{P}<0.05$

Table 11: Amino acids profile in serum of healthy and diseased calves (Mean \pm SE).

\begin{tabular}{|c|c|c|c|c|c|c|c|c|c|c|c|c|c|c|c|}
\hline Parameters & \multirow[b]{2}{*}{$T h r$} & \multirow[b]{2}{*}{ Met } & \multirow[b]{2}{*}{ Ilu } & \multirow[b]{2}{*}{ Leu } & \multirow[b]{2}{*}{ Phe } & \multirow[b]{2}{*}{ His } & \multirow[b]{2}{*}{ Lys } & \multirow[b]{2}{*}{ Arg } & \multirow[b]{2}{*}{ Val } & \multirow[b]{2}{*}{ Ser } & \multirow[b]{2}{*}{ Glu } & \multirow[b]{2}{*}{ Gln } & \multirow[b]{2}{*}{ Aln } & \multirow[b]{2}{*}{ Cys } & \multirow[b]{2}{*}{$T y r$} \\
\hline & & & & & & & & & & & & & & & \\
\hline \multirow{2}{*}{$\begin{array}{l}\text { Control } \\
\text { Group }\end{array}$} & 2.62 & 2.45 & 4.69 & 6.98 & 2.92 & 6.85 & 3.70 & 5.62 & 6.92 & 5.82 & 4.86 & 9.84 & 10.62 & 2.68 & 2.02 \\
\hline & \pm 0.01 & \pm 0.04 & \pm 0.33 & \pm 0.41 & \pm 0.043 & \pm 0.061 & \pm 0.11 & \pm 0.04 & $\mathbf{\pm 0 . 0 1}$ & \pm 0.06 & \pm 0.34 & \pm 0.98 & \pm 0.64 & \pm 0.08 & \pm 0.17 \\
\hline \multirow{3}{*}{$\begin{array}{c}\text { Infected } \\
\text { Group }\end{array}$} & & $*$ & $*$ & $*$ & $*$ & & * & $*$ & * & * & * & $*$ & $*$ & & \\
\hline & 2.21 & 1.78 & 3.25 & 4.16 & 1.11 & 6.65 & 1.86 & 4.12 & 4.28 & 3.62 & 3.29 & 8.11 & 6.82 & 2.94 & 2.45 \\
\hline & \pm 0.18 & \pm 0.02 & \pm 0.21 & \pm 0.09 & \pm 0.015 & $\mathbf{\pm 0 . 0 7}$ & \pm 0.04 & \pm 0.11 & \pm 0.017 & \pm 0.14 & \pm 0.61 & \pm 0.08 & \pm 0.52 & \pm 0.03 & $\mathbf{\pm 0 . 1 5}$ \\
\hline
\end{tabular}

The mean difference is significant at the $\mathrm{P}<0.05$ 
Table 12: DNA fragmentation percentage and some oxidative stress indicators in healthy and diseased calves $($ Mean \pm SE).

\begin{tabular}{|c|c|c|c|c|c|c|c|c|c|}
\hline $\begin{array}{c}\text { Parameter } \\
\text { Groups }\end{array}$ & $\begin{array}{c}\text { DNA } \\
\text { fragmentation } \\
\%\end{array}$ & $\begin{array}{c}\text { MDA } \\
(\mathrm{nmol} / \mathrm{ml})\end{array}$ & $\begin{array}{c}\text { SOD } \\
(\mathbf{U} / \mathbf{m l}) \mathbf{u} / \mathbf{l}\end{array}$ & $\begin{array}{c}\text { Glutathion- } \\
\text { S-transferase } \\
(u / l)\end{array}$ & $\underset{(\mu \mathrm{gu} / \mathrm{dl})}{\mathrm{Cu}}$ & $\begin{array}{c}\mathbf{Z n} \\
(\mu \mathrm{g} / \mathrm{dl})\end{array}$ & $\begin{array}{c}\text { Fe } \\
(\mu \mathrm{g} / \mathrm{dl})\end{array}$ & $\begin{array}{c}\text { VitA } \\
(\mu \mathrm{g} / \mathrm{dl})\end{array}$ & $\begin{array}{r}\text { Vit E } \\
(\mu g / d l)\end{array}$ \\
\hline $\begin{array}{l}\text { Control } \\
\text { Group }\end{array}$ & $\begin{array}{l}39.80 \\
\pm 0.55\end{array}$ & $\begin{array}{l}16.90 \\
\pm 0.36\end{array}$ & $\begin{array}{c}31.4 \\
\pm 0.19\end{array}$ & $\begin{array}{r}64.80 \\
\pm 1.73\end{array}$ & $\begin{array}{c}28.12 \\
\pm 0.06\end{array}$ & $\begin{array}{c}\mathbf{3 4 . 1 8} \\
\mathbf{+ 0 . 0 7 7}\end{array}$ & $\begin{array}{r}140.13 \\
\pm 0.005\end{array}$ & $\begin{array}{r}33.12 \\
\pm .003\end{array}$ & $\begin{array}{c}3.44 \\
\pm 0.12\end{array}$ \\
\hline $\begin{array}{l}\text { Infected } \\
\text { Group }\end{array}$ & $\begin{array}{c}12.22 * \\
\pm 0.09\end{array}$ & $\begin{array}{r}64.82 * \\
\pm 0.27\end{array}$ & $\begin{array}{l}19.80 * \\
\pm 0.75\end{array}$ & $\begin{array}{c}36.60 * \\
\pm 0.65\end{array}$ & $\begin{array}{l}17.77 * \\
\pm 0.09\end{array}$ & $\begin{array}{c}25.68 * \\
\pm 0.074\end{array}$ & $\begin{array}{c}122.17 * \\
\pm 0.04\end{array}$ & $\begin{array}{l}21.72 * \\
\pm 0.018\end{array}$ & $\begin{array}{l}2.76 * \\
\pm 0.07\end{array}$ \\
\hline
\end{tabular}

The mean difference is significant at the $\mathrm{P}<0.05$

The mean difference is significant at the $\mathrm{P}<0.05$

\section{DISCUSSION}

Diarrhea is one of the most common diseases reported in calves up to three months old (Svensson et al., 2003). Neonatal calf diarrhea is considered one of the most serious constraints of animal production.

The incidence of calf diarrhea occurs allover the year with some increase in calving season. (Elham et al., 2012).

In this study Bacteriological examination of fecal samples revealed that $\mathrm{E}$ coli was the most prominent cause of calf diarrhea at an incidence of $54.1 \%$, followed by Salmonella species at an incidence of $17.5 \%$ then Campylobacter at an incidence of $10.8 \%$. Proteus vulgaris was isolated at an incidence of $10 \%$ then Pseudomonas at an incidence of $6.7 \%$. Our findings are nearly similar to (Elham et al., 2012) who stated that, the total bacteria isolated from faeacal samples were E. coli, S.typhimurium, Campylobacter and P. aeruginosa with incidence of 47.5, 9, 7.5 and 4, respectively. E. Coli was the most common bacteria isolated from fecal samples of diarrheic calves, (China et al., 1996 and Harbby, 2002). Also the results agreed with that obtained by El-Hamamy et al. (1999), who recorded that cultures of swabs from diarrheic calves revealed that, the predominant isolate was E-coli (52.5\%), enterobacter aerogense (15\%), Proteus vulgaris $(12.5 \%)$ and Salmonella spp.(5\%).

Also the results of (Ibrahim, 2007) revealed that 7 of 150 samples were positive for E-coli with an incidence of $24.66 \% .13$ samples, out of 150 samples $22.7 \%$ were positive for Campylobacter; Salmonella were isolated in 22 samples with an incidence of $14.66 \%$.

Serological identification of 65 E. coli isolates, revealed that the isolated $\mathrm{E}$. coli were typed as $\mathrm{O} 157$ (38.5\%), O119 (23.1\%), O25 (7.7), O111 (7.7\%), O186 (15.4\%), and un typable E. coli isolates (7.7\%).

These findings are similar to Elham et al. (2012) who concluded that the serological serotyping of $95 \mathrm{E}$. coli isolates, revealed that $\mathrm{E}$. coli were typed as K99(21.1\%), O157 (17.9\%), O111 (9.5\%), O125 (11.6\%), O119 (15.8\%), O26(12.6\%), O128 (8.4\%) and un typed E. coli (3.2\% to \%). Also (Tamaki et al., 2005). Stated that the most common E. coli serotypes isolated from diarrheic fecal samples were O119, O111, O126, and O78.

Bacteriological examination revealed the isolation of Salmonella from diarrheic calves as well as apparently healthy contact calves. S.typhimurium was the most predominant serovars (52.4\%) which indicates that S.typhimurium is the most predominant serovars causing enteritis in calves. S. enteritidis (33.3\%) and 3 strains (14.3\%) were untypable. The results agree with the results of (Jones et al., 1988; Segall and Lindberg, 1993; Seleim et al., 2004). Also Moussa et al. (2010) collected Fecal samples from diarrheic calves as well as apparently healthy contact calves and showed high incidence of Salmonella serovars 43.52 and $27.69 \%$, respectively. S.typhimurium was the most predominant serovars (17.65 in diarrheic calves and $15.38 \%$ in contact apparently healthy calves). while S. enteritidis (8.24 and 4.62 respectively).

Antibiotics should only be used for E. coli and Salmonella infection, after sensitivity test to choose the best drug, as inappropriate use of antibiotics can lead to serious antibiotic resistance problems (Yimer Muktar et al., 2015).

Results of antibiogram revealed that, (ciprofloxacin, cephalexineand ofloxacin) were the most effective antibiotics for treatment of diarrheic calves. Most isolated bacteria showed different degrees of resistance to Ampicillin,Cefotaxime, Gentamycine.

Elham et al. (2012) mentioned that the in vitro sensitivity of recovered isolates of E.coli from diarrheic fecal samples to different antimicrobial agents were highly sensitive to enrofloxacin, flumequine and tetracycline. In contrast, these isolates were found to be resistant to ampicillin, erythromycin, gentamicin, lincomycin and penicillinG. 
The present results agreed with those of Sadiek and Sohair (1999), who studied antibiotic sensitivity of fecal samples from diarrheic calves and found that enrofloxacin was the antibiotic of choice for most bacterial isolates (E. coli, Salmonella species, and Proteus species).

Owing to the resistance pattern of isolated $\mathrm{E}$ coli strains against some antibiotics of B lactam group using the traditional disc diffusion antibiogram method, it was a must to detect the blaTEM gene using PCR as a recent, rapid and accurate method to facilitate medication of affected calves.

PCR results revealed that $16(88.9 \%)$ out of 18 examined E coli strains encoding blaTEM gene while only two $(11.1 \%)$ strains were negative.

Similar results were reported by Aziz et al. (2014) who concluded that $(90 \%)$ of examined E-coli strains encoding blaTEM gene.

The hematological changes recorded in diarrheic calves and control calves are depicted in table (9) revealed a significant $(\mathrm{P}<0.05)$ decrease in the $\mathrm{RBCs}$ number and $\mathrm{Hb}$ concentration these results come in accordance with Knowles et al. (2000) Hood and Skaar (2012). Anzaldi, and Skaar (2010) suggested that, during infection, hemolytic bacterial cytotoxins damage host cells, leading to damage to the endothelium of the small vessels, followed by disseminated intravascular coagulation and finally, signs of anemia.

Platelet count was considerably lower in calves with diarrhea than in the control group as recorded previously by Sobiech et al. (2013) and Gokce et al. (2006) pointed out that during bacterial infection thrombocytopenia may be due to platelets destroyedin large number following antigen-antibody reactions on the platelets surface membrane or excessive consumption of platelets to fulfill their normal role in hemostasis occurs during diarrhea.

Moreover, significant leukocytosis may be due to bacterial infection and inflammatory lesions which acted promptly causing neutrophilia with lymphopenia which is characteristic of acute bacterial enteritis. Abdalla et al. (2000) and Khan and Zaman (2007).

The results of total serum protein, albumin and globulin values in calves suffering from enteritis (group II), are recorded in tables (10). They revealed a significant $(\mathrm{p}<0.05)$ decrease in serum total proteins albumin levels, $\mathrm{A} / \mathrm{G}$ ratio and significant increase $(p<0.05)$ in serum globulin as recorded previously by Abdalla et al. (2000) and Fouad et al. (2008). This could be referred to the inflammation or ulceration of gastrointestinal tracts which lead to impaired absorption of protein as well as increased protein loss Moreover, destructive effect of bacteria and bacterial toxins on the liver cells, may be attributed to inhibition of its synthesis, its rapid breakdown, Tothova et al. (2012) stated that serum albumin is the major negative acute phase protein, during the acute phase response the demand for amino acids for synthesis of the positive acute phase proteins is markedly increased, which necessitates reprioritization of hepatic protein synthesis. Thus, albumin synthesis is down-regulated and amino acids are shunted into synthesis of positive acute phase proteins, Moreover, the increase in serum globulins could be referred to the inflammatory process and the immune response antibodies.

A significant increase $(\mathrm{p}<0.05)$ in serum urea nitrogen and serum creatinine values in diarrheic calves was recorded as compared to control. The increase in both the parameters was in consistent with the report by (Ghanem et al., 2012. Nasir et al., 2013 and Singh et al., 2014). The significant increase in serum urea nitrogen and creatinine in the present study was attributable to dehydration, concentration of the plasma solutes as a result of diarrhea, deficit in renal blood perfusion (glomerular filtration rate) and reduced urine formation (Asma et al., 1996), also, it could be attributed to increased utilization of amino acids for production of urea by catabolism of body protein in severe toxic condition (Sreedhar et al., 2013).

Table (10) declared that there was significant decrease in glucose concentration $(p<0.05)$ in diarrheic calves in comparison with the control. This significant decrease come in accordance with Fatma and Kawther (2007) and Singh et al. (2014). This significant decrease may be occurred as a result of reduced rate of conversion of lactic acid to glucose, decreased intestinal absorption of glucose from damaged intestinal epithelium and alternation in tissue metabolism caused by decreased blood flow and oxygenation associated with hypovolemic shock low glucose reserve, inhibit glyconeogensis and decrease glycolysis (Abdalla et al., 2000).

Acute enteric infections are characterized by the rapid development of dehydration and electrolytes imbalance which are believed to be responsible for many of the clinical signs (emaciation, weakness, turgor of the skin, sunken eyes), extreme metabolic acidosis, hemoconcentration and hypofunction of kidneys and liver (Dratwa et al., 2012). The present study revealed significant $(\mathrm{p}<0.05)$ decrease in serum sodium and increased serum potassium concentration in diseased calves in comparison with control as recorded previously by Dratwa et al. (2012) and Nasir et al. (2013). Hyponatreamia in diarrheic calves due to an excessive secretion of sodium along with water into intestinal lumen. Hyperkalemia was due to increased potassium retention by kidney and also due 
to its movement from intracellular to the extracellular fluid in response to the acidosis as diarrhea is often accompanied by a metabolic acidosis which is a result of the loss of carbohydrates and also from organic acid accumulation (Seifi et al., 2006).

Table (11) demonstrated that serum amino acid analysis showed significant $(\mathrm{P}<0.05)$ decrease in serum essential amino acids [threonine (Thr), methionine (Met), Isoleucine (Ilu), leucine(Leu), Phenyl alanine (Phe), lysine(Lys), arginine(Arg) and valine $(\mathrm{Val})$ ] and non-essential amino acids [serine (ser), glutamic acid (glu), glycine (gln) and alanine (aln)] in calves with diarrhea compared with normal calves, these results come in accordance with (Waggoner et al., 2009 and Tsukano et al., 2015).

The observed decline in Met in our study may be due to an increase in Met transsulfuration, because metabolic demand for Cys and S-adenosylmethionine increases during inflammation (Li et al., 2007). Cysteine is required for the production of acute-phase proteins production of the free radical scavenger, glutathione, (Wu et al., 2004), and production of cytokines involved in the immune response are stimulated by S-adenosylmethionine (Grimble, 2006) Also, decreases in plasmaLeu and Ile could be because lymphocytes preferentially utilize the branched-chain AA during inflammation as substrates for protein synthesis (i.e., antibody production) or energy production (Calder, 2006). Glutamine is synthesized from glutamate and ammonia by glutamine synthetase so the significant decrease in glutamic acid consequently decrease the synthesis of glutamine (Carneiro et al., 2003).

The amino acid glutamine is the fundamental respiratory fuel for the small intestine and has been classified as a conditional essential amino acid ,Glutamine maintain the intestinal immunologic barrier, since it has been shown to increase the intestinal immunoglobulin A levels and to reduce bacterial translocation, which it reduces the incidence of bacteremia infections. In addition, glutamine has also been postulated as a regulator of intracellular kinases, apoptosis, cell proliferation and redox status, (Wischmeyer et al., 2001). Glutamine is a precursor for nucleotide synthesis, serves as a substrate for hepatic gluconeogenesis, and is an important nutrient for the renal handling of ammonia. It is also an important fuel source for cells that rapidly turn over, including GI epithelia, lymphocytes, fibroblasts, and reticulocytes (Carneiro et al., 2003).

Results shown in table (12) revealed significant $(\mathrm{P}<0.05)$ increase in DNA fragmentation percentage and MDA level accompanied with significant decrease in some enzymatic antioxidant (glutathione $-S$ - transferase and SOD) and non-enzymatic antioxidants ( $\mathrm{Su}, \mathrm{Fe}, \mathrm{Zn}$ Vit $\mathrm{A}$ and $\mathrm{E}$ ) concentration in the affected calves compared to control group. Oxidative stress related to diarrhea has been implicated as a major initiator of tissue damages and can affect enzymatic activity, signal transcription and gene expression, especially apoptotic gene (AbdElrahman 2011) Since SOD degrades the superoxide into oxygen and hydrogen peroxide which are less toxic substances its low level leads to accumulation of oxidant substances and free radical that caused cellular damage to the intestinal lining mucosa It could also a result of hypocuppremic occurring in diarrhea where $\mathrm{Cu}$ is the major activator of SOD (Dupont et al., 2011).

Apoptosis is a non-inflammatory response to tissue damage characterized by a series of morphological and biochemical changes, fragmentation of genomic DNA into multimers of $180-200 \mathrm{bp}$ is one of the feature of apoptosis (Rohwer and Azam. 2000), the significant increase in DNA fragmentation percentage in infected calves in comparison with healthy calves may be due to high concentration of the thiolactivated enterotoxins produced by Enterobacteriaceae increases the production of reactive oxygen species(ROS), which would contribute to toxin-induced inflammation and lysis of leukocytes before triggering apoptosis Barnes et al. (2001). However, Moss et al. (2000) reported that bacteria kills macrophages and epithelial cells by secreting adenylatecyclase-haemolysin toxin, which increases cAMP levels, an increase in the intracellular concentration of cAMP leads to apoptosis of host cells.

(Wischmeyer et al., 2001) stated that glutamine has also been postulated as a regulator of intracellular kinases, apoptosis, so the significant decrease in glutamine as recorded in table (12)increase the DNA fragmentation in infected calves as glutamine upregulates antiapoptotic proteins and down-regulates proapoptotic proteins so the significant decrease in glutamine induces apoptosis by caspase- 3 and caspase-8 sequential activation in $\mathrm{T}$ lymphocyte (Carneiro et al., 2006), Another potential mechanisms of Gln action is the pathway of glutathione, an antioxidant compound that detoxifies reactive oxygen species and has potent anti apoptotic effects (Mates et al., 2002). The amide nitrogen of glutamine is essential for purine and pyrimidine biosynthesis (Evans et al., 2005).

The significant decrease in $\mathrm{Fe}, \mathrm{Cu}, \mathrm{Zn}$, Vit $\mathrm{A}$ and $\mathrm{E}$ come in accordance with Ghanem et al. (2012) Tajik and Nazifi $(2013)$ The significant decrease $(\mathrm{P}<0.05)$ in these minerals and vitamins might be attributed to decrease in absorption of food nutrient through the intestine and losses in feces and reservoir in the liver will be considerably reduced (Khan et al., 2009). (Anzaldi, and Skaar 2010) pointed out that the significant decrease in iron in infected calves may 
be due to pathogenic bacteria use several strategies to acquire iron to multiply in infected cells, during infection, hemolytic bacterial cytotoxins damage host cells, leading to the release of ferritin, this iron is carried out by secreted bacterial siderophores (lowmolecular-mass chelators) that specifically bind $\mathrm{Fe}^{+3}$ and transport it into the cytoplasm leading to reduction of the iron in serum infected calves. Moreover, low plasma zinc concentration may be due to losses of this electrolyte through the digestive tract, increased zinc requirements for immune system and also utilization of its stores in tissues for synthesis of antioxidative enzymes (Ranjan et al., 2006).

Deficiency of vit. A is characterized by degeneration and drying of the mucosal epithelium of the intestinal tract, vitamin A-deficient calves suffered from depressed activity of natural killer cells, decreased antibody production, decreased responsiveness of lymphocytes to mitogenic stimulation, and increased susceptibility to infection (Rajaraman et al., 1998). The significant decrease in vit. E may be attributed to stress condition and increase of its uptake in response to oxidative stress as vit $\mathrm{E}$ acts as a chain-breaking antioxidant, neutralizing free radicals and preventing oxidation of lipids within membranes (Weiss 2005).

\section{CONCLUSION}

Antibiotics should only be used for E. coli and Salmonella infection, after sensitivity test to choose the best drug, as inappropriate use of antibiotics can lead to serious antibiotic resistance problems.

Detect of the blaTEM gene using PCR as a recent, rapid and accurate method is very important to facilitate medication of diarrheic calves.

Biochemical results showed that bacterial infection causes deficiency in most essential amino acids increase fragmentation of DNA and production of more ROS, impaired fluid electrolyte and altered blood parameters Thus, these parameters should be used as a useful tool for diagnosis, prognosis, and evaluation of the therapy applied and should be monitored during the treatment of calves.

\section{REFERENCES}

Abdalla, O.M.; EL-Hammamy, M. and Ramada, T.M. (2000): Some hematological and biochemical alteration on pneumonia and enteritis of the neonatal calves. 5th Vet. Med. Zag. Conference Sharm E 1- Sheik. 58-65.

Abd-Elrahman, A.H. (2011): Colibacillosis in newly born buffalo calves and role of lacteal forte in preventing recurrence of calf diarrhea. Life Science Journal 8: 497-502

Anzaldi, L.L. and Skaar, E.P. (2010): Overcoming the heme paradox: heme toxicity and tolerance in bacterial pathogens. Infect. Immun. 78, 49774989.

Asma, O.A.; Abd El-Wahed, Z.H.; Kohl, K.M. and ElShikh, A.R. (1996): Some studies on clinical, hematological and biochemical changes in diarrheic neonatal buffalo calves with reference to hygienic conditions. Assuit. Vet. Med. J., 35(69): 91-101

Aziz, H.M.; Hala, F. Habashy; Amany N. Dapgh and Dalia, M. Mohsen (2014): Prevalence of pathogenic E.coli in diarrhoeic calves with special reference to antibiotic resistance genes. AHRI J. vol. 2 No. 3

Barnes, A.I.; Paraje, M.G.; D C. Batta' N.P. and Albesa, I. (2001) : Molecular properties and metabolic effect on blood cells produced by a new toxin of Enterobacter cloacae. Cell BiolToxicol 17, 409-418.

Bartels, C.J.; Holzhauer, M.; Jorritsma, R.; Swart, W.A. and T.J. Lam (2010): Prevalence, prediction and risk factors of enteropathogens in normal and non-normal faeces of young Dutch dairy calves. Prev Vet. Med. 169-93: 162.

Bauer, A.W.; Kirby, M.M.; Sheris, J.S. and Turek, M. (1966): Antibiotic sensitivity testing by single disc method. Am. J. Clin. Pathol.; (45): 939396.

Calder, P.C. (2006): Branched-chain amino acids and immunity. J. Nutr. 136:288-293.

Carneiro, F.B.A.; Bushen, O.Y.; Brito, G.A.; Lima, A.A. and Guerrant, R.L. (2003): Glutamine analogues as adjunctive therapy for infectious diarrhea. Curr Infect Dis Rep5: 114-119.

Carneiro, B.A.; Fujii, J.; Brito, G.A.; Alcantara, C.; Oria, R.B.; Lima, A.A.; Obrig, T. and Guerrant, R.L. (2006): Caspase and bid involvement in Clostridium difficile toxin Ainduced apoptosis and modulation of toxin A effects by glutamine and alanyl-glutamine in vivo and in vitro. Infect.Immun. 74, 81-87.

China, B.; Pirson, V. and Mainil, J. (1996): Typing of bovine attaching and effacing Escherichia coliby multiplex in vitro amplification of virulence-associated genes. Appl. Environ. Microbiol. 62: 3462-3465.

Chirino-Trejo, J.M. (1999): A more sensitive procedure for the detection of Salmonella carriers in swine.Proc. Western Candian Assoc. Swine Pract. 50-53.

Csomos, E. and Sarkadi, L. (2002): Characterization of free amino acid and biogenic amine using ion-exchange chromatography. Chromatographia Supplement. 56: 185-88.

Dratwa, C.A.; Herosimczyk, A.; Lepczyñski, A. and Skrzypczak, W.F (2012): Calves with diarrhea and a water-electrolyte balance Medycyna Wet. 2012, 68 (1) 5-8.

Duff, G.C. and Galyean, M.L. (2007): Board-Invited Review: Recent advances in management of 
highly stressed, newly received feedlot cattle. J. Anim. Sci. 85: 823-840.

Dupont, C.L.; Grass, G. and Rensing, C. (2011): Copper toxicity and the origin of bacterial resistance-new insights and applications. Metallomics 3, 1109-1118.

Edwards, P.R. and Ewing, W.H. (1972): Identification of Enterobactericeae. Burgess publCo. Minnece polis, Minnesota, 103-104

Elham, I.A.; Eman, M.S. and. Eman, M.Z. (2012): Bacterial diarrhea in newly born calves in Menoufiea Governorate. Assiut Vet. Med. J. 58. 126-137.

El-Hamamy, M.M.; El-Boushi, M.E. and Fataih, H.A. (1999): Some studies on newly born calves' problems with relationship to their immune status. SCVM J, II (2): 289.

Evans, M.E.; Jones, D.P. and Ziegler, T.R. (2005): Glutamine inhibits cytokine-induced apoptosis in human colonic epithelial cells via thepyrimidine pathway. Am. J. Physiol. 289, 388-396.

Fatma M.Y. and Kawther, H.S. (2007): Biochemical and bacteriological evaluation of different water supply used in farm animals and its effect of animal health .SCVMJ, XII (2) 225238.

Fazlani, SA.; Khan, SA.; Faraz1, S. and Awan, MS. (2011): Antimicrobial susceptibility of bacterial species identified from mastitic milk samples of camel. J. African of Biotech; Vol. 10 (15), pp. 2959-2964.

Fouad, E.S.; Magda, M.M.; Mokhtar A.A. and Sahar, E.S. (2008): Trial for the use of serum protein electrophoresis as a diagnostic tool for some diseases in buffaloes calves. SCVMJ, XIII (2) 511-528

Gershwin, L.J. (1990): The physiochemical and biological basis of immunity. In: Biberstein, E.L., Zee, Y.C. (Eds.): Review of Veterinary Microbiology. Blackwell Scientific Publications, Boston, USA. 29-30.

Ghanem, M.M.; EL-Fkhrany, S.F.; AbdeL-Raof.; Y.M. and EL-Attar, H.M. (2012): Clinical and hematobiochemical evaluation of diarrheic neonatal buffaloo calves with reference to antioxidant changes .BVMJ 23(2) 275-288.

Gokce, G.; Gokce, HI.; Erdogan, HM.; Gunes, V. and Citil, M. (2006): Investigation of the coagulation profile in calves with neonatal diarrhea. Turk J Vet AnimSci 30: 223-227.

Grimble, R.F. (2006): The effects of sulfur amino acid intake on immune function in humans. $J$. Nutr. 136: 1660-1665.

Habig, W.M. and Jakoby, W.C. (1974): Estimation of glutathione-S- transferase. J. Biol. and Chem., 249: 7130.

Harbby, H.A. (2002): Bacterial causes of diarrhea in small animals (Kids, lambs and calves) in
Sultanate of Oman. J. Egypt. Vet. Med. Ass., 62 (3): 227

Hawk, P.P.; Oser, P.L. and Summerson, W.H. (1954): Determination of vit $\mathrm{E}$ in (Practical Physiology Chemistry) McGraw-Hill BooK Company, Inc. New York, Toronto, London pp 1272-1276.

Hood, M.I. and Skaar, E.P. (2012): Nutritional immunity: transition metals at the pathogenhost interface. Nat. Rev. Microbiol. 10, 525537.

Hughes, LE.; Gibson, EA.; Roberts, HE.; Davies, ET.; Davies, G. and Sojka, WJ. (1971): Bovine salmonellosis in England and Wales. Br Vet. J. 238-127: 225.

Ibrahim, E. (2007): Studies on microbial causes of diarrhea in calves. M.V.Sc. Thesis, Fac. Vet. Med., Kafr El-Sheikh Univ.

Izzo, M.M.; Kirkland, P.D.; Mohler, V.L.; Perkins, N.R.; Gunn, A.A. and J.K. House. (2011): Prevalence of major enteric pathogens in Australian dairy calves with diarrhoea. Aust Vet J . 173-89:167.

Jain, N.C. (2000): Schalm's Veterinary Haematology 5th Ed. Lea and Febiger, Philadelphia.

Jones, P.W.; Collins, P. and Aitken, M.M. (1988): Passive protection of calves against experimental infection with S. typhimurium. Vet. Rec. 123: 536-41.

Kaper, J.B.; Nataro, J.P. and Mobley, H.L. (2004): Pathogenic Escherichia coli. Nat Rev Microbiol 132.(2) 1495.

Khan, A. and Zaman, T. (2007): Effects of rehydration solution on hematological and biochemical parameters in induced buffalo neonatal calf diarrhea. Ital. J. anim. Sci. 6 (2) 957-960.

Khan, J.A.; Khan, M.S.; Khan, M.A.; Avis, M.; Maqbool, A.; Salman, M. and Rehman, Z. (2009): Epidemiology of major bacterial and viral causes of diarrhea in buffalo calves in three districts of the Punjab Province of Pakistan. Pak. J. Zool. Suppl. 9: 179-188.

Klein, D.; Alispahic, M.; Sofka, D.; Iwersen, M.; Drillich, M. and F. Hilbert (2012): Prevalence and risk factors for shedding of thermophilic Campylobacter in calves with and without diarrhea in Austrian dairy herds. J. Dairy Sci. 96: 1203-1210.

Knowles, T.G.; Edwards, J.E.; Bazeley, K.J.; Brown, S.N.; Butterworth, A. and Warriss, P.D. (2000): Changes in the blood biochemical and haematological profile of neonatal calves with age. Veterinary Record 147, 593-598.

Koneman, E.W.; Allen, S.D.; Dowell, V.R.; Janda, W.H. and Sommers, H.M. (1992): Color atlas and Textbook of Diagnostic Microbiology. $4^{\text {th }}$ Ed., J.B.Lippincott CO., New York.

Kresse, A.U.; Rienacker, I.; Valle, A.M.; Steinruck, H.; Claus, H. and Payne, S.M. (2007): 
Enterohaemorrhagic Escherichiacoli 0157 and non-O157 serovars differ in their mechanisms for iron supply. Int. J. Med. Microbiol. 297,9-15.

Li, P.; Yin, Y.; Li, D.; Kim, S.W. and Wu. G. (2007): Amino acids and immune function. Br. J. Nutr. 98: 237-252.

Mates, J.M.; Perez-Gomez, C.; Nunez de Castro, I.; Asenjo, M. and Marquez, J. (2002): Glutamine and its relationship with intracellular redox status, oxidative stress and cell proliferation/ death. Int. J. Biochem. Cell Biol. 34, 439-458

Mert, S. and Henkin, R. (1971): Simultaneous direct estimation by AAS of copper and zinc in serum, urine and CSF. Clin. Chem. 17: 369379.

Milton, J.S. and Toskos, J.O. (1985): Statistical methods in Biological and Health Sciences Mc Grow Hill book.

Morifnigo, M.A.; Borrego, J.J. and Romero, P. (1986): Comparative study of different method for detection and enumeration of Salmonella spp. in natural waters Appl. Bacteriol. 61: 169176.

Moss, J.E.; Idanpaan-Heikkila, I. and Zychlinsky, A. (2000): Induction of apoptosis by microbial pathogens. In Cellular Microbiology, pp. 409423. Edited by P. Cossard, P. Bouquet, and S. Normark.

Moussa, I.M.; Mohamed, K.H.F.; Al-Doss, A.A.; Ashgan, M.S. and Mohamed, M.S. (2010): Rapid detection of Salmonellaspecies in newborne calves by polymerase chain reaction. International Journal of Genetics and Molecular Biology Vol. 2 (4), pp. 062-066,

Nasir, A.A.; Younus, M.; Rehman, M.U.; Lateef, M.; Khaliq, S.A.; Ahmad, I. and Abbas, M. (2013): Hematological and some biochemical alterations in sheep experimentally infected with clostridium perfringens typed D infection. The Journal of Animal \& Plant Sciences, 23(6): 1553-1558.

Nataro, J.P. and Kaper J.B. (1998): Diarrheagenic Escherichia coli. Clin. Microbiol Re 2-11: 142.

National Committee for Clinical laboratory Standards (NCCLS) (2002): Performance and dilution susceptibility test for bacteria isolates from animals "Aproved Standers" $2^{\text {nd }} E d$. M3t Az .NCCL. Wayne Pennsylvania، USA.

Oh Kawa, H.W.; Ohish, W. and Yag, I.K. (1975): Determination of malondialdehyde. Anal. Biochem. 95: 351 .

Perandones, C.E.; Luera, V.A.; Peckman, D.; Stunz, L.L. and Ashnan, R.F. (1993): Regulation of apoptosis in vitro in matiso murine spleen $\mathrm{T}$ cells. J. of Immunol, 151 (7): 3521.

Powanda, M.C. and Beisel, W.R. (2003): Metabolic effects of infection on protein and energy status. J. Nutr 133: 322S-327.

Quinn, P.J.; Carter, M.E.; Markey, B.K. and Carter, G.R. (1994): Clinical Veterinary
Microbiology. Mosby. Yearbook Europe Limited.

Rajaraman, V.; Nonnecke, B.J.; Franklin, S.T. and Hammell, D.C. (1998): Effect of vitamins A and $\mathrm{E}$ on nitric oxide production by blood mononuclear leukocytes from neonatal calves fed milk replacer. J. Dairy Sci., 81: 3278.

Ranjan R.; Naresh, R.; Patra, R.C. and Swarup, D. (2006): Erythrocyte lipid peroxides and blood zinc and copper concentrations in acute undifferentiated diarrhoea in calves. Vet. Res. Commun., 30, 249-254.

Rohwer, F. and Azam, F. (2000): Detection of DNA damage in prokaryotes by terminal deoxyribon ucleotidetrans ferase-mediated dUTP nick end labeling. Appl. Environ. Microbiol. 66: 10011006.

Sadiek, A. and Sohair, Z.H. (1999): Acute enteritis in neonatal calves in Sohag governorate with special reference to aetiology, clinicochemical aspects and therapy. Assuit Vet. Med. J., 42(83): 200-212.

Segall, T. and Lindberg, AA. (1993): Oral vaccination of calves with an aromatic S.dublin $(09,12)$ hybrid expressing 04, 12 protects against Salmonella Dubillin $(09,12)$ bill not against $S$. typhimurium $(04,5,12)$. Infect. Immun. 61: 1222-1231.

Seifi, H.A.; Mohri, M.; Shoorei, E. and Frzaneh, N. (2006): Using hematological and serum biochemical findings as prognostic indicators in calf diarrhoea. Comp. Clin. Pathol. 2006, 15, 143-147.

Seleim, R.S.; Sahar, R.; Novert, M.H. and Gohran, R.A. (2004): Salmonella infection in calves: virulence proteins and its immunogenic properties. J. Vet. online.

Singh, M.; Gupta, V.K.; Mondal, D.B.; Bansal, S.K.; Sharma, D.K.; Shakya, M. and Gopinath, D. (2014): A study on alteration in Haematobiochemical parameters in Colibacillosis affected calves. International Journal of Advanced Research, 2, (7): 746-750.

Sobiech, P.; Rękawek, W.; Ali, M.; R. Targoński, R. and Żarczyńska, K. (2013): Changes in blood acid-base balance parameters and coagulation profile during diarrhea in calves P. J. of Vet. Sci. 16 (3): 543-549.

Sojka, W.J.; Wray, C.; Shreeve, J. and Benson, A.J. (1977): Incidence of salmonella infection in animals in England and Wales 1968- 1974 J. Hyg 78: 43-56.

Sreedhar, S.; Rao, K.S.; Suresh, J.; Patrapalle, R.S. and Moorthy, S. (2013): Changes in haematocrit and some serum biochemical profi le of Changes in haematocrit and some serum biochemical profi le of Sahiwal and Jersey $x$ Sahiwal cows in tropical environments Sahiwal and Jersey $\times$ Sahiwal cows in tropical environments. Vet. arhiv 83 (2), 171-187. 
Suzuki, I. and Katoh, N. (1990): A Simple method for measuring serum vit $A$ in cattle using spectrophotometer. Jap. J. of Vet. Sci. 52: 1281-1283.

Svensson, C.; Lundborg, K.; Emanuelson, $U$. and Olsson, S.O. (2003): Morbidity in Swedish dairy calves from birth to 90 days of age and individual calf-level risk factors for infectious diseases. Prev. Vet. Med. 58(3): 179-197.

Tajik, J. and Nazifi, S. (2013): A preliminary study of the correlations of serum concentrations of electrolytes and trace elements with clinical signs in diarrheic dairy calves. Pak Vet. J., 33(1): 5-8.

Tamaki, Y.; Narimatsu, H.; Miyazato, T.; Nakasone, N.; Toma, C. and Iwanaga, M. (2005): The relationship between $\mathrm{O}$ antigens and pathogenic genes of diarrhea-associated E. coli. Jpn. J. Infect. Dis., 58: 65-69.

Tsukano, K.; Suzuki, K.; Shimamori, T.; A Sato, A.; Kudo, K.; Asanos, R.; Ajito, T. and Lakritz, J. (2015): Profiles of serum amino acids to screen for catabolic and inflammation status in calves with Mycoplasma bronchopneumonia. J. Vet. Med. Sci. 77(1): 67-73.

Waggoner, J.W.; Loest, C.A.; Turner, J.L.; Mathis, C.P. and Hallford, D.M. (2009): Effects of dietary protein and bacterial lipopolysaccharide infusion on nitrogen metabolism and hormonal responses of growing beef steers. J. Anim. Sci. 87: 36563668 .
Wakeman, C.A. and Skaar, E.P. (2012): Metalloregulation of Grampositive pathogen physiology. Curr. Opin. Microbiol. 15, 169174.

Weiss, W.P. (2005): Antioxidants nutrients, cow health and milk quality. Dairy Cattle Nutrition Workshop, Department of Dairy and Animal Sciences, Penn State, p. 11-18.

WHO. (1977): Expert committee on Biological standardization. Technical reportserics 610 . WHO. Geneva .

Wischmeyer, PE.; Lynch, J.; Liedel, J.; Wolfson, R.; Riehm, J. and Gottlieb, L. (2001): Glutamine administration reduces Gram-negative bacteraemia in severely burned patients: a prospective, randomized, double-blind trial versus isonitrogenous control. Crit Care Med; 29: 2075-2080.

Woolliams, J.A.; Wiener, G.; Anderson, P.H. and Murray, C.H. (1983): Variation in activities of glutathione peroxidase and superoxide dismutase and in the concentration of copper in the blood in various breed crosses of sheep. Res. Vet. Sci.; 34: 253-256.

Wu, G.; Fang, Y.; Yang, S.; Lupton, J.R. and Turner, N.D. (2004): Glutathione metabolism and its implications for health. J. Nutr. 134: 489-492.

Yimer Muktar; Gezhagne Mamo; Biruk Tesfaye and Dinaol Belina (2015): A review on major bacterial causes of calf diarrhea and its diagnostic method. Journal of Veterinary Medicine and Animal Health. 7(5): 173-185.

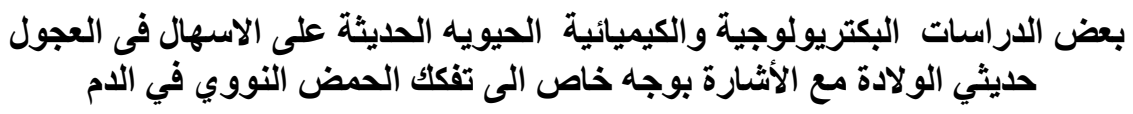

سحر أحد أحد على ، نجلاء صالح عبل الله ، عطبية عبل الله الجداوي

Email: dr.attia31@yahoo.com Assiut University web-site: www.aun.edu.eg

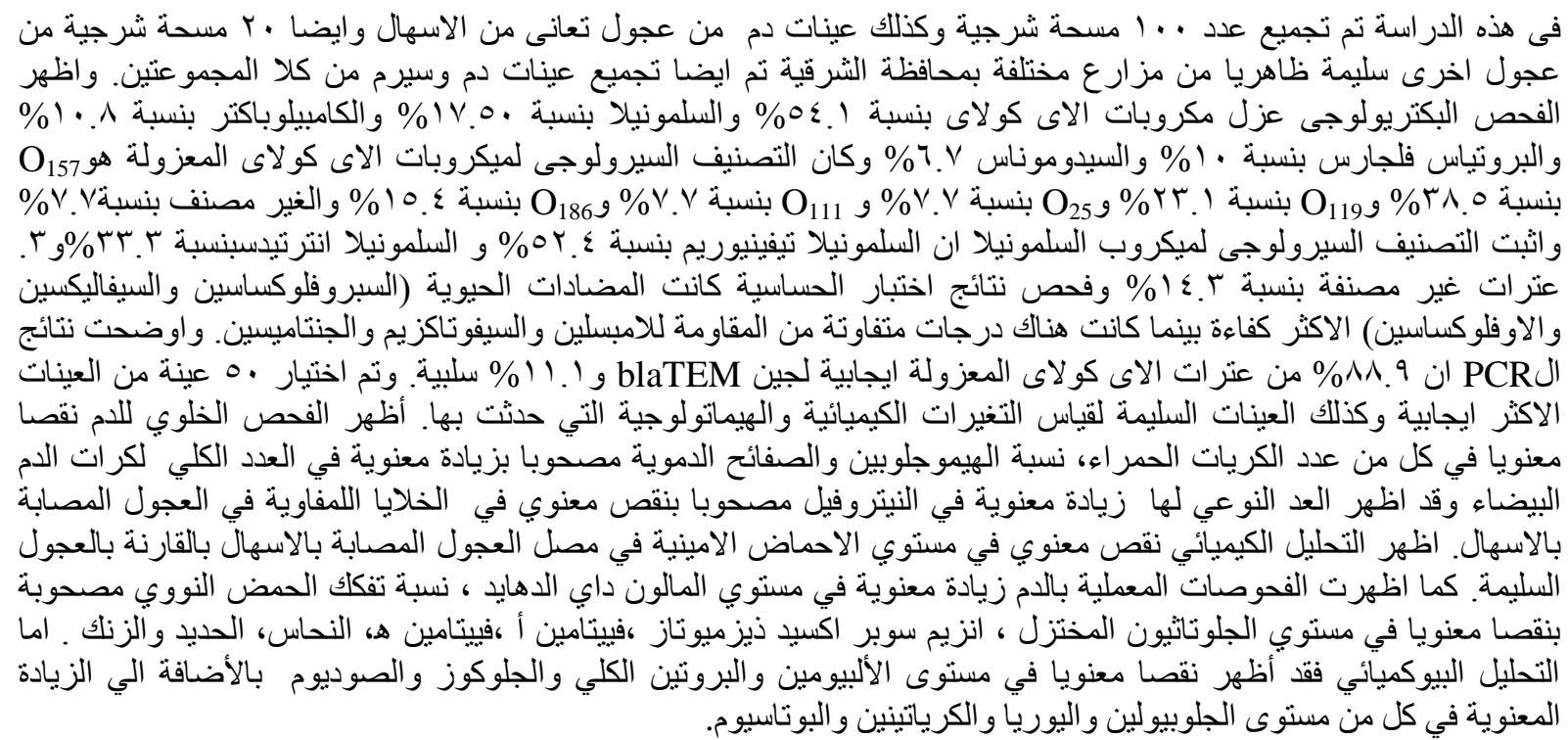

